\title{
Opkomst en voortbestaan van de Derde Weg
}

\author{
Het raadsel van de missende veren
}

Merijn Oudenampsen ${ }^{*}$

\begin{abstract}
'Sie sang das alte Entsagungslied, Das Eiapopeia vom Himmel, Womit man einlullt, wenn es greint, Das Volk, den großen Lümmel. Ich kenne die Weise, ich kenne den Text, Ich kenn auch die Herren Verfasser; Ich weiß, sie tranken heimlich Wein Und predigten öffentlich Wasser.'
\end{abstract}

Heinrich Heine, Ein Wintermärchen

Het is geen controversieel gegeven: de PvdA verkeert al jaren in een identiteitscrisis. De partij zou onder Wim Kok haar ideologische veren hebben afgeschud. Terugkerende intentieverklaringen - door vooraanstaande partijleden als Cohen, Spekman en Duijvestein bijvoorbeeld - om de ideologische veren weer op te plakken roepen vaak de nodige scepsis op: opgeplakte veren, dat klinkt niet als een solide constructie. De meest voorkomende lezing is dan ook dat de PvdA nog steeds het aanzien heeft van een geplukte kip. De huidige electorale problemen van de partij zouden voortkomen uit feit dat het een pragmatische club is zonder inspiratie, zonder visie, zonder ideologie. Dat is ook het terugkerende beeld in de vele journalistieke analyses van het afgelopen decennium: de partij weet simpelweg niet meer waar zij voor staat. In dit artikel wordt een genuanceerdere stelling verdedigd: de PvdA hangt nog immer het sociaalliberalisme van de Derde Weg aan, dat echter gecombineerd wordt met sociaaldemocratische getuigenispolitiek. Het weifelachtige geschipper tussen deze twee polen - tussen praktijk en profiel, politieke en electorale overwegingen - heeft velen doen concluderen dat de partij niet weet wat ze wil.

De Britse Derde Weg is eens gekscherend beschreven als een monster van Loch Ness - iedereen heeft ervan gehoord, er komen af en toe ooggetuigenverslagen over binnen, maar niemand is er zeker van dat het beest werkelijk bestaat. Als gevolg van de ambigue houding van de PvdA ten opzichte van de Derde Weg lijkt dat des te meer te gelden in Nederland. Deze relatieve onzichtbaarheid kan tevens een verklaring bieden voor het feit dat in vergelijking met omliggende landen, waar de opkomst van deze stroming tot een ware hausse aan academische studies

* Merijn Oudenampsen is promovendus bij het Departement Cultuurwetenschappen van Tilburg University. 
heeft geleid, ${ }^{1}$ er in Nederland relatief weinig over geschreven is. Hetgeen dat geschreven is, behandelt de Derde Weg bovendien overwegend als neutraal partijoverstijgend beleid (Spithoven, 2002; Merkel e.a., 2008; Green-Pedersen, Van Kersbergen \& Hemerijck, 2001; Hoop, 2004) en in mindere mate als politiek gedachtegoed (De Beus \& Notermans, 2000; Green-Pedersen \& Van Kersbergen 2002), waar in deze tekst de interesse naar uitgaat. De discussiebijdragen van partijleden zelf (onder meer: Wöltgens, 1998; Van Kersbergen, 2000; De Beus, 2000; Becker \& Cuperus, 2002; De Beer, 2004; Bos, 2010) vormen zo de hoofdmoot van de literatuur over de Nederlandse Derde Weg. Maar partijleden schrijven natuurlijk niet geheel vrij en belangeloos. 'Versluiering van politieke macht en politieke strevingen is in elk politiek stelsel een der middelen der regeren', stelde de politicoloog Hans Daalder (1995, 39) al eens.

Met die gedachte in het achterhoofd wordt in dit artikel op kritische wijze de Nederlandse worsteling met de Derde Weg behandeld. Dat gebeurt in vijf stappen: het artikel opent met een korte introductie van de Derde Weg, waarbij de weerstand om publiekelijk de koerswending te expliciteren als onderscheidende factor van de Nederlandse Derde Weg wordt geïdentificeerd. Vervolgens wordt de belangrijkste stelling van dit artikel verder uiteengezet, namelijk dat de identiteitscrisis van de PvdA verbonden is met het impliciete karakter van de Nederlandse Derde Weg. Daarna zal een korte revisie plaatsvinden van het ontstaan en voortbestaan van de Nederlandse Derde Weg, opgedeeld in drie verschillende periodes. Om te beginnen de opkomst van de Derde Weg onder Wim Kok wanneer er een geruchtmakende publieke breuk is met het socialisme maar Kok afstand houdt tot de Derde Weg ideologie zoals uitgedacht in de V.S. en het V.K. Ten tweede de periode onder Ad Melkert en Wouter Bos, wanneer Derde Weggers openlijk als zodanig uit de kast komen, maar dat door de kritiek op 'de puinhopen van paars' niet doorzetten. Als derde en laatste stap komt de draai naar het gemeenschapsdenken onder Diederik Samsom en Lodewijk Asscher aan bod, een aspect dat in de Britse en Amerikaanse Derde Weg vanaf het begin aanwezig was en dat grote overlap vertoont met het recente pleidooi voor een participatiesamenleving.

Tot slot is een kwalificerende opmerking hier nog op zijn plaats: het verhaal van de Nederlandse Derde Weg dat hier verteld zal worden heeft een focus op de PvdA, de belangrijkste vertolker van dit gedachtegoed. De uitstraling van de Derde Weg in Nederland is echter breder dan de PvdA en bestrijkt alle middenpartijen. Zo gebruikte bijvoorbeeld het CDA lange tijd het Derde Weg communitarisme en het concept van het 'radicale midden' als uitgangspunt voor zijn koers (CDA, 2012). Ook de VVD kan als regeringspartner van de PvdA en als voorstander van de participatiesamenleving niet helemaal los gezien worden van deze politiek. 'Waar de Derde Weg paars was en waar PvdA bleef duister', stelde Wouter Bos $(2010,7)$ terecht in zijn Den Uyl lezing, een uitspraak die evenzeer opgaat voor het tweede kabinet-Rutte. Daarbij zijn bepaalde fenomenen die hier

1 Lukes (2000, p100) oppert grappend 'dat de voorstanders van de Derde Weg deze hebben uitgevonden om academici zoals wij bezig te houden'. 
geschaard worden onder de Derde Weg niet uniek voor dit gedachtegoed. Cuperus (2000) constateerde dat de Nederlandse politiek 'vrijwel automatisch Derde-Wegposities produceert door het coalitiestelsel en het permanent 'meeregeren' van de sociale partners'. ${ }^{2}$ Sommige van de op de volgende pagina's behandelde elementen zijn inmiddels bijna vanzelfsprekendheden in de modernisering van het politieke bedrijf sinds de jaren negentig, zoals de door Bart Tromp (2010) beschreven opkomst van de campagnepartij. Dat bredere kader gaat de reikwijdte van dit artikel echter te buiten. ${ }^{3}$

\section{De Derde Weg, een introductie}

De Derde Weg ontstond in het midden van de jaren negentig als een strategie van centrumlinkse partijen om verloren politieke relevantie te herwinnen. De Keynesiaanse receptuur waar linkse partijen lange tijd hun politiek op baseerden, raakte in de jaren tachtig in diskrediet. De term Derde Weg werd door politici als Bill Clinton en Tony Blair naar voren geschoven om een veelomvattende politieke heroriëntatie aan te geven: een nieuwe koers die een middenweg behelsde tussen de oude Keynesiaanse politiek en het neoliberalisme van Reagan en Thatcher. Deze koersverandering had zowel een meer beleidsmatig, als een politiek-electoraal, als een meer ideologisch aspect, alhoewel de drie niet helemaal te scheiden zijn. Het beleid van de Derde Weg gaat grof gesteld uit van het idee dat de markt op veel terreinen effectiever is dan overheidsinterventie. Door meer ruimte te geven aan de markt wordt extra economische groei gerealiseerd, die de overheid in staat stelt flankerend sociaal beleid te realiseren. Een gezaghebbend - maar niet altijd even neutraal - overzicht van Derde Weg beleid is het bekende BlairSchröder paper (1999), dat in de academische literatuur (Green-Pedersen, Van Kersbergen \& Hemerijck, 2001) als maatgevend wordt gezien. ${ }^{4}$ Het paper vermeldt een waslijst aan beleidsmaatregelen waaronder: belastinghervorming gericht op verlaging van arbeidskosten en verbetering van het ondernemersklimaat; een monetaristisch macro-economisch beleid gericht op reductie van begrotingstekorten door het bezuinigen op de publieke uitgaven; de introductie van

2 'PvdA moet zich met overtuiging op de Derde Weg richten', NRC Handelsblad, 3 maart 2000.

3 Maar zie De Beus (2002) en Blommaert (2007).

4 Eigen aan de Derde Weg, dat gelijk opging met de popularisering van Amerikaanse PR- en campagnetechnieken in de Europese politiek, was het feit dat de retoriek een sterke marketinginslag had. Feitelijke politieke keuzes gingen vaak schuil achter vage begrippen als 'modernisering' en 'globalisering' (Fairclough 2000). Dat werkt door tot in de academische literatuur, ook omdat deze soms is geschreven door voorstanders van de Derde Weg. Een van de zeldzame studies over de Nederlandse Derde Weg vat deze politiek samen als bestaande uit een 'robuust macro-economisch beleid', 'responsieve loonakkoorden', 'een actief arbeidsmarktbeleid' en 'een efficiënt fiscaal en sociaal beleid' (Green-Pedersen et al. 2001, 309). Dit zijn weinig neutrale termen. Het lijkt me lastig een politieke stroming te vinden die geen voorstander is van een 'robuust', 'responsief', 'actief' en 'efficiënt' beleid. Opvallend verder aan het Blair-Schröder paper en bijvoorbeeld het door Green-Pedersen en Van Kersbergen geschreven artikel over de Derde Weg is dat privatisering niet expliciet genoemd wordt, een sleutelingrediënt van het beleid van de Derde Weg. Dat kan een politieke reden hebben. Net als het feit dat de verwevenheid met het neoliberalisme door aanhangers van de Derde Weg sterk gerelativeerd wordt. 
New Public Management in de publieke sector; hervorming van de sociale zekerheid door uitkeringen afhankelijk te maken van de plicht tot werken; een actief arbeidsmarktbeleid, waaronder subsidiëring van werkgevers om moeilijk bemiddelbaren in dienst te nemen; en flexibilisering en deregulering van arbeids-, kapitaal- en productmarkten. De Derde Weg onderscheidt zich van het neoliberalisme door de actieve rol die zij de staat toebedeelt om burgers te activeren en op te leiden om zich op succesvolle wijze ten gelde te kunnen maken op de markt. Daarnaast is er het politiek-electorale aspect dat bestaat uit een verschuiving naar het politieke en electorale midden, naar een positie Beyond Left and Right, de titel van een bekende publicatie van de Britse Derde Weg-ideoloog Anthony Giddens. Electoraal gezien werd er gesproken van een oriëntatie op het 'sociologische midden' (Becker \& Cuperus, 2002), wat grof gesteld een verschuiving in doelgroep van arbeidersklasse naar middenklasse betekende. Bij de Britse en Amerikaanse Derde Weg betekende deze middenpositie eveneens een overname van rechtse law \& order thema's, wat in continentaal Europa aanvankelijk minder navolging vond. Het ideologische aspect bestaat uit een Derde Weg discours dat het eerder genoemde beleid moreel en ideologisch legitimeert in termen van gemeenschapszin, eigen verantwoordelijkheid en ondernemerschap (opportunity). Dit in scherp contrast met de ideologische en morele fundering van de naoorlogse sociaaldemocratie, die gebouwd was op de drieslag solidariteit, economische zekerheid, en sociale rechtvaardigheid.

Om een wat kortere beschrijving te geven, in een essay voor partijblad Socialisme \& Democratie uit 2000, getiteld De onontkoombaarheid van de 'derde weg' omschreef de politicoloog Kees van Kersbergen het in de volgende (soms wat gekleurde) termen:

'Kort samengevat, springen bij de 'derde weg'-ideologie de volgende zaken in het oog:

- de herontdekking van de markt als positief te waarderen (en politiek in te zetten) mechanisme van sociaaleconomische sturing;

- het streven naar een transformatie van de welvaartsstaat, van een passieve, op het verstrekken van uitkeringen gericht, bureaucratisch en gecentraliseerd monster, naar een op maximale participatie, zowel op de arbeidsmarkt als daarbuiten, georiënteerde sociale investeringsstaat die macht decentraliseert;

- een heroverweging van het door de oude sociaaldemocratie gekoesterde gelijkheidsideaal, van gelijkheid van uitkomsten, in het bijzonder inkomensnivellering, naar gelijkheid van hulpbronnen en kansen en gelijkheid als sociale insluiting;

- het opnieuw overdenken van de waarde van solidariteit in termen van een balans tussen rechten en plichten die gelden voor iedere burger;

- een heroverweging van de electorale en politieke coalities, zowel binnenlands als buitenlands, zowel politiek als economisch, die het draagvlak voor het derde-weg beleid dienen te vormen en de sociaaldemocratie in 
de eenentwintigste eeuw een nieuwe kans op machtsvorming bieden.' (Van Kersbergen, 2000, 280)

In Van Kersbergens definitie zien we de eerder genoemde elementen terugkomen: een beleidsmatige visie, een ideologische legitimering van dat beleid in termen van waarden als gelijkheid (sociale rechtvaardigheid) en solidariteit, en de politiek-electorale verschuiving naar een politieke middenpositie. Het is daarbij duidelijk dat de Derde Weg een poging is om een ideologische breuk te markeren ten opzichte van de Keynesiaanse sociaaldemocratische traditie. Echter de mate waarin de Derde Weg een afscheid van de sociaaldemocratie inhoudt, of juist een voortzetting daarvan met andere middelen, blijft een vrij subjectieve definitiekwestie. Wel is het belangrijk om op te merken dat de Derde Weg, in tegenstelling tot wat er soms in de bestaande literatuur wordt beweerd (Green-Pedersen, Van Kersbergen \& Hemerijck, 2001, 307; Bos 2010), niet enkel een voortzetting van sociaaldemocratische principes en doelen is met andere middelen, maar wel degelijk een heroverweging behelst van die waarden en doelen zelf. De eerder genoemde drieslag van sociaaldemocratische waarden is duidelijk verwoord in Kees Schuyts studie Op zoek naar het hart van de verzorgingsstaat. Schuyt $(1992,5)$ reduceert daarin de materiële en morele grondslagen van de verzorgingsstaat tot drie kernpunten:

1. 'Solidariteit: niemand mag onder de grens zakken, waaronder een decent bestaan in een vrije maatschappij onmogelijk wordt.

2. Sociale rechtvaardigheid: de verdeling van inkomen en daarvan afgeleide schaarse goederen mag niet door willekeur tot stand komen.

3. Een economische politiek gericht op zo veel mogelijk werkgelegenheid voor ieder als de beste bestrijding van de financiële problemen van de 'staat van verzorging'.

Op al deze terreinen zagen Jos de Beus en Ton Notermans (2000) onder de Derde Weg nieuwe principes naar voren geschoven worden. Ten eerste wordt solidariteit in termen van wederkerigheid begrepen. De auteurs schrijven over Blairs formule 'geen recht zonder verantwoordelijkheid', waarin verleende sociale rechten gelijk opgaan met een plicht van burgers om een productieve bijdrage aan de gemeenschap te leveren, waaronder ook gezinszorg, vrijwilligerswerk, en publiek dienstverlening vallen. Ten tweede, sociale rechtvaardigheid wordt op basis van de filosofie van Rawls gereduceerd tot het welbevinden van de laagste inkomens, waarbij grotere inkomensgelijkheid geaccepteerd wordt. De vraagstimulering van het keynesianisme wordt ingeruild voor een aanbodbeleid (supply-side economics) dat de nadruk legt op de positieve rol van de staat in het bevorderen van de nationale concurrentiepositie. Het gaat vergezeld van een pleidooi 'voor een afgeslankte, meer doelmatige en activerende welvaartsstaat die de individuele neiging economische risico's te nemen vergroot' en wordt mede mogelijk gemaakt door sociale akkoorden (De Beus \& Notermans 2000, 84). Ten derde krijgt onder het monetaristische beleid bestrijding van inflatie voorrang en wordt conjunctuurwerkloosheid aanvaard. Werkloosheid wordt meer een persoonlijke verantwoordelijkheid. 
Dit gaat samen met het streven van delegatie van macht aan centrale banken en de nadruk op beheersing van de overheidsschuld door het snijden in de publieke uitgaven.

Deze contrasten tussen traditionele sociaaldemocratie en Derde Weg zijn in Nederland echter nooit heel duidelijk uit de verf gekomen. De discussie hierover heeft zich tot een kleine kring beperkt. Nederland neemt daardoor in het academische debat over de Derde Weg een aparte positie in. De PvdA wordt internationaal gezien als voorloper van de Derde Weg van Blair en Clinton, de partij volgde zogezegd een 'derde weg' koers avant la lettre' (Green-Pedersen \& Van Kersbergen, 2002, 508). Volgens Green-Pedersen, Van Kersbergen, en Hemerijck (2001, 320) kunnen we met recht spreken van een Nederlandse Derde Weg, 'in de zin van een redelijk coherente set van beleidsvoorstellen' die veel overeenkomsten vertonen met de suggesties uit het Blair-Schröder paper. Het Nederlandse voorbeeld wordt zelfs als een navolgenswaardig 'model' gepresenteerd voor andere sociaaldemocratische partijen (Green-Pedersen, Van Kersbergen \& Hemerijck, 2001, 309). Tegelijkertijd echter hebben politici van de PvdA altijd een behoedzame afstand gehouden tot de ideologie van de Derde Weg, en zich er nimmer volledig mee willen associëren. 'Gek eigenlijk', zo constateerde PvdA partij-intellectueel Jos de Beus al terugblikkend op de periode onder Wim Kok, 'vrijwel alle prominente staatslieden en commentatoren in het buitenland associëren Koks leiderschap met de Derde Weg, maar in de keuken van Kok zelf lijkt de Derde Weg een discussie om de discussie waar de PvdA naar believen buiten wil blijven.' (De Beus, $2000,13)$

Dit strookt met vergelijkende internationale analyses waarin geobserveerd wordt dat een 'uitgewerkt en expliciet Derde Weg discours prominent was in slechts een relatief klein aantal landen, voornamelijk de VS en het VK', waar elders een vergelijkbaar beleid 'meer sluipenderwijs' werd ingevoerd (Lewis \& Surender, 2004, 8). Waarom, zo luidt de ook voor ons relevante vraag 'ontpopten Democratische en Labour-politici in deze twee landen zich tot openlijke vaandeldragers voor dit toch controversiële en risicovolle pad, terwijl andere Europese en centrumlinkse regeringen dezelfde hervormingen doorvoerden met minder trompetgeschal?' (Lewis \& Surender, 2004, 8) De Australische casus die de auteurs vervolgens opvoeren, biedt een interessante parallel voor de Nederlandse ontwikkelingen. In Australië was van 1983 tot 1996 een Labour-regering aan de macht die radicale hervormingen doorvoerde die later als inspiratie voor de Britse en Amerikaanse Derde Weg zouden dienen. Deze hervormingen werden door de Australische Labour Party (ALP) echter naar buiten toe gepresenteerd als onderdeel van de mainstream van de Australische Labour traditie. Het neo-corporatistische bestel in Australië, de zoektocht naar consensus en bovenal de noodzaak om de vakbonden binnenboord te houden worden gezien als voornaamste redenen om geen grote ideologische breuk te markeren (Lewis \& Surender, 2004, 18-19).

Een vergelijkbare ontwikkeling lijkt zich in Nederland te hebben voorgedaan. Wim Kok hield een behoedzame afstand tot de Derde Weg, zelfs al werd hij door Bill Clinton op het schild gehesen als voorganger van deze stroming. Wouter Bos 
presenteerde in zijn Den Uyl-lezing uit 2010 de Derde Weg als 'mainstream sociaaldemocratie, niet meer en niet minder' (Bos, 2010, 6). Nochtans, al presenteert een partij zich naar buiten toe als een baken van continuïteit, dan zal het alsnog een discours moeten ontwikkelen dat intern, het nieuwe beleidsparadigma ideologisch legitimeert en begrijpelijk maakt voor het partijkader. Als er binnen de partij bovendien sprake is van strijd tussen aanhangers van de Derde Weg en meer traditionele sociaaldemocraten (Van Praag, 1991; Wolinetz, 1996), dan is het onvermijdelijk dat de Derde Weg expliciet verdedigd en uiteengezet wordt. De discussies binnen de PvdA zijn een grillige getuige van deze problematiek, waarbij de partij over de tijd heen is blijven laveren tussen publieke omarming van de Derde Weg en relativering van de sociaalliberale breuk met haar sociaaldemocratische verleden. De zich voortslepende identiteitscrisis van de PvdA, zo luidt de stelling van dit artikel, is een product van deze weifelachtige houding, die doorwerkt tot op de dag van vandaag. Want hoewel de Derde Weg meerdere malen vroegtijdig publiekelijk dood is verklaard in Nederland - bijvoorbeeld in $2000^{5}$, in $2002^{6}$, en in $2010^{7}$ - speelt de reeks aan politieke attitudes, strategieën en beleidsvoorstellen die onder die noemer haar intrede vond, nog steeds een vitale en voorname rol in de Nederlandse politiek.

\section{Het raadsel van de missende veren}

Het raadsel van de missende ideologische veren is een terugkerende discussie die de gemoederen al jaren bezig houdt, zo niet decennia. Bij geen andere partij is de eigen identiteitscrisis tot op een dergelijke hoogte onderdeel gaan uitmaken van de partijcultuur. De Volkskrant-columnist Sheila Sitalsing stelde eind 2014 dat er 'eeuwigheidswaarde schuilt in het zinnetje dat voormalig PvdA-voorzitter Ruud Koole' opschreef in een analyse uit 1993: 'De huidige positie van de PvdA kan niet anders dan met het woord 'crisis' getypeerd worden.'8 Koole schreef deze inmiddels tot tegeltjeswijsheid verheven zin in een vergelijkende analyse van de worsteling die Europese sociaaldemocratische partijen doormaakten in de vroege jaren negentig. Een tijd die in het teken stond van de moeizame overgang van het oude sociaaldemocratische gedachtegoed naar het nieuwerwetse sociaalliberalisme van de Derde Weg. 'Een partij kan niet alleen opvattingen opgeven, zij moet daar ook iets voor in de plaats stellen,' zo verwoordde Koole $(1993,93)$ de zoekende houding uit die tijd. Een uitspraak die zich evenzeer voor een tegeltje leent. 'Ideeënvorming en niet zomaar een 'leuk ideetje' kan de basis leggen voor het herstel van de $\operatorname{PvdA}(1993,95)$, concludeerde de latere partijvoorzitter zijn analyse.

$5 \quad$ 'De Derde Weg loopt dood in Berlijn', NRC Handelsblad, 2 juni 2000.

6 'De Derde Weg loopt dood', NRC Handelsblad, 11 januari 2002.

7 Als voorbeelden: 'PvdA-leider neemt afstand van de Derde Weg en wil marktwerking inperken', Het Parool, 26 januari 2010; 'Een diepe greppel tegen het ongebreidelde kapitalisme: PvdA-leider Wouter Bos neemt in Den Uyl-lezing afstand van sociaaldemocratische hervormingsbeweging 'Derde Weg”, NRC Handelsblad, 26 januari 2010; 'Bos maakt schoon schip', Vrij Nederland, 30 januari 2010; 'De Weg van Wouter Bos', Elsevier, 30 januari 2010, p. 3.

8 'PvdA heeft geen idée waar het voor staat', De Volkskrant, 14 november 2014. 
We kunnen stellen dat Koole op zijn wenken werd bediend. Een jaar later, in 1994, trad Tony Blair aan als leider van de Britse Labour partij. Hij zou samen met de socioloog Anthony Giddens de grootste vertolker en popularisator worden van de Derde Weg, het politieke verhaal dat de plaats zou gaan innemen van het oude sociaaldemocratische gedachtegoed in bijna geheel Europa (Giddens, 1998; Hale, Leggett \& Martell 2004, Lewis \& Surender 2004, Merkel e.a. 2008). Zoals reeds vermeld is het specifieke aan de Nederlandse context dat de PvdA uit electorale overwegingen ervoor zou kiezen om zich naar buiten toe nimmer helemaal te vereenzelvigen met de Derde Weg. Het nieuwe verenkleed zou slechts zeer weifelend en daarbij overwegend in kleine kring tentoongesteld worden. Met als gevolg dat de discussie over de identiteit van de partij telkens bleef terugkeren.

Om een impressie te geven van het zich repeterende karakter van deze discussie, grenzend aan het tragikomische: in 1993 stelt Ruud Koole dat 'de belangrijkste reden voor de crisis van de PvdA' erin gelegen is dat zij 'niet in staat [is] een helder sociaal-democratisch antwoord op de sociaal-economische problemen van deze tijd te formuleren' (Koole, 1993, 92). Met de regeringsdeelname in 1989 had de partij haar oude 'heilige huisjes' losgelaten, maar men had moeite om daar iets voor in de plaats te stellen. In 1998, na deelname aan Paars I, vraagt toenmalig PvdA-senator Thijs Wöltgens of de PvdA doorgaat met Paars of dat zij gebruik maakt van 'een geschikte kans om haar eigen identiteit zichtbaar te maken' (Wöltgens, 1998, 371). In 2002, na de dramatische verkiezingsoverwinning van de LPF, wordt de crisis binnen de PvdA (een verlies van 22 zetels) door partijintellectuelen geweten aan het feit dat de 'sociaal-liberale middenkoers' nauwelijks geïnternaliseerd is door de partij wat leidde tot een noodlottig 'gebrek aan overtuigingskracht en sense of direction dat de PvdA uitstraalde' (Becker \& Cuperus, 2002, 85). Na een verlies van 8 zetels in de verkiezingen van 2006, verschijnt er een artikel in het NRC Handelsblad met als ondertitel 'De PvdA verkeert in crisis', waarin verschillende partijprominenten zich afvragen wat de PvdA eigenlijk voor partij is en welke achterban zij nog bedient. ${ }^{9}$ Het partijrapport uit die tijd van de commissie-Vreeman beschrijft hoe 'de politieke visie waarmee Wouter Bos aan het partijleiderschap was begonnen', niet bezonken was 'in de hearts and minds van de partijleden' en 'teveel alleen de zijne bleef' (PvdA, 2007, 15). In februari 2012, met het vertrek van Job Cohen die een linksere koers voorstond, kopt Trouw: 'De PvdA zit in ongekende crisis'. Het artikel concludeert: 'Er is niemand met een overtuigend idee van wat de positie van de $\operatorname{PvdA}$ zou moeten zijn.' ${ }^{10}$ Eind 2014, wanneer een hernieuwde crisis optreedt omdat de partij een historisch dieptepunt in de peilingen bereikt, is het verhaal als vanouds 'dat de PvdA geen idéé heeft waar het voor staat'. ${ }^{11}$

$\mathrm{Nu}$ is het gegeven dat de $\operatorname{PvdA}$ regelmatige politieke crises doormaakt niet uniek voor de partij. Het uitzonderlijke is dat iedere keer opnieuw, onduidelijkheid lijkt

9 'Witte arbeider, waar bent u; PvdA'ers over de crisis in hun partij' NRC Handelsblad, 2 juni 2007.

10 'Vertrek Cohen is niet meer dan symptoombestrijding, de PvdA zit in ongekende crisis', Trouw, 21 februari 2012.

11 'PvdA heeft geen idée waar het voor staat', De Volkskrant, 14 november 2014. 
te bestaan over wat het verhaal van de partij eigenlijk is en wat dat zou moeten zijn. $\mathrm{Nu}$ zou een partij waarbinnen geen duidelijk idee of geen consensus bestaat over de eigen politiek een zeer chaotisch en stuurloos gegeven moeten zijn, incapabel tot regeren. Er is veel over de PvdA te zeggen, maar stuurloos is de partij toch zeker niet. Bij onenigheid over de te volgen koers in de partij - denk aan de crisis rond de SP-flirt van Cohen of de nacht van Duijvestein - lijkt er juist zeer resoluut ingegrepen te worden. Intrigerend is dat de vaststelling van identiteitsloosheid in bovengenoemde analyses paradoxaal genoeg veelal samen gaat met de vaststelling dat het sociaalliberalisme van de Derde Weg dominant is binnen de partij. Dat stellen partijideologen Frans Becker en René Cuperus na de ondergang van paars in 2002 (Becker \& Cuperus, 2002). Diederik Samsom stelt op zijn beurt in het genoemde NRC-artikel uit 2007 dat de Derde Weg 'nog altijd domineert in de PvdA'. En de opstandige senator Adri Duijvestein stelt in 2014 op schijnbaar eufemistische wijze dat 'de sociaal-liberale vleugel nogal sterk vertegenwoordigd is in de partijtop'. ${ }^{12}$

Het stereotype beeld dat door de jaren heen in de media is ontstaan, als zou de PvdA geen verhaal hebben, geen idee waar het voor staat, moet daarom met de nodige scepsis worden benaderd. De PvdA, in ieder geval de partijtop, lijkt heel goed te weten waar de partij voor staat. Wie de teksten van derdeweggers als Bos, Cuperus, Vermeend, Van der Ploeg, Timmermans, Bussemaker, Dijsselbloem en Asscher leest, wie de toespraken terugziet van Bos en Asscher bij de internationale Derde Weg-denktank Policy Network, vindt daar een duidelijke en redelijk coherente sociaalliberale lijn. Dat verhaal ligt echter niet goed bij de achterban, en de partijtop heeft nimmer helemaal openlijk durven uitkomen voor het nieuwe gedachtegoed.

De politieke denker Steven Lukes stelde eens dat de dubbelzinnigheid van de Britse Derde Weg retoriek ertoe diende om ideologische conflicten te verhullen en 'politieke leiders in staat te stellen om hun eigen doelen na te streven en tegelijkertijd de stemmen van ideologisch georiënteerde kiezers te winnen.' (Lukes, 2000, 100) Waarschijnlijk geldt dit des te meer voor de Nederlandse Derde Weg. In tegenstelling tot de Angelsaksische landen heeft Nederland geen districtenstelsel. Het electorale midden is als gevolg daarvan minder belangrijk en de PvdA is kwetsbaarder voor concurrentie op links. Er is dus een grotere noodzaak om de linkse kiezer binnenboord te houden. Dat bleek al tijdens de crisis over de WAOhervorming in de jaren negentig, die de PvdA flinke electorale schade toebracht en leidde tot de entree van de SP in de Tweede Kamer (Wolinetz, 1995). En dat concludeerde partijideoloog René Cuperus ook na een verkiezingsnederlaag in 2006: 'Bos wilde vanaf het begin de Nederlandse Tony Blair zijn. Hij zocht het midden op om de grootste partij te worden. Maar dat werkt alleen, zo is gebleken, in een tweepartijenstelsel. In Nederland valt meteen de linkervleugel open en komt de SP op. De achterban is veel linkser en traditioneler dan de partijtop denkt. ${ }^{13}$ Vanaf begin af aan is er dus sprake van een vertaalprobleem, dat logi-

12 'Ik stam uit de tijd van zwart en wit', NRC Handelsblad, 20 december 2014

13 'Witte arbeider, waar bent u; PvdA'ers over de crisis in hun partij' NRC Handelsblad, 2 juni 2007. 
scherwijs opdoemt als een politieke doctrine wordt geïmporteerd van de ene context naar de andere. In Nederland resulteert dit niet enkel in ambigu taalgebruik maar ook in ideologische dubbelzinnigheid: de partij combineert een nieuwerwetse sociaalliberale koers met een ouderwets sociaaldemocratisch profiel. Op 1 mei zingt de PvdA nog steeds De Internationale. Bij jubilea koestert de partij op nostalgische wijze de socialistische traditie waar zij onder Kok publiekelijk mee gebroken heeft. Positieve referenties aan de democratisch socialist Den Uyl sieren de toespraken van 'derde weggers' als Wouter Bos en Diederik Samsom En partijvoorzitter Spekman riep onlangs nog op om 'krachten [te] bundelen tegen het grootkapitaal'. ${ }^{14}$

Historisch gezien is deze houding geenszins een noviteit in Nederland. De politicoloog Hans Daalder stelde in zijn inaugurele rede van 1964 - Leiding en lijdelijkheid in de Nederlandse politiek - dat centrisme en dubbelzinnigheid kernelementen vormen van de Nederlandse politieke cultuur. Daalder spreekt van een 'centristische mythologie', waardoor politieke tegenstellingen en verantwoordelijkheden versluierd worden ten gunste van het compromis. Dat leidt ertoe dat 'vele wezenlijk-politieke zaken in de Nederlandse samenleving niet als zodanig gesteld worden' (Daalder, 1995, 15). Het gefragmenteerde karakter van de verschillende twintigste-eeuwse emancipatiebewegingen, (socialisten, katholieken, kleine luyden) heeft er volgens Daalder toe geleid dat de Nederlandse emancipatiebewegingen eerder deel zijn gaan uitmaken van deze regenteske en centristische bestuurscultuur, dan er daadwerkelijk oppositie tegen te voeren. Een apart soort dualisme was het gevolg. De bewegingen richtten zich in het parlement op getuigenispolitiek (het verkondigen van de waarden van de eigen achterban, zonder daadwerkelijk over te gaan tot effectieve politieke organisatie om deze waarden te realiseren), en namen genoegen met een sterk gereduceerde invloed op het regeringsbeleid. Het idee van de regering als een neutraal gegeven, boven alle partijen verheven, bleef daardoor in zwang. Dit ten voordele van 'quasi neutralistische stromingen' binnen diezelfde partijen en wat Daalder de 'geheel kleurloze middenstof' noemt, 'nuances op het politieke spectrum die de traditionele regenten en vele nieuwe bureaucraten exacter pasten dan de nieuwe bevolkingsgroepen, die tot politieke bewustheid kwamen.' (Daalder, 1995, 25)

De beschreven combinatie van sociaaldemocratische getuigenispolitiek en sociaalliberaal beleid zou ook de terugkerende klacht kunnen verklaren, dat discussies binnen de partij enerzijds zo'n kritische - ja zelfs masochistische - lading hebben en anderzijds zo weinig beklijven. Zo stelde het rapport van de commissie-Vreeman - De scherven opgeruimd (PvdA, 2007) - waarin de verkiezingsnederlaag uit 2006 werd geanalyseerd, dat de conclusies van vorige rapporten - zoals De kaasstolp aan diggelen, dat de verkiezingsnederlaag uit 2002 analyseerde - nimmer op bevredigende wijze tot onderwerp van discussie zijn gemaakt. Van het rapport van de commissie-Vreeman kan iets vergelijkbaars gezegd worden. De Canadese politicoloog Steven Wolinetz vergeleek de PvdA al eerder met een patiënt die door 
een dokter een verandering van levensstijl wordt aangeraden, maar immer stug doorgaat op oude voet (Wolinetz, 1993, 109).

\section{Ontstaan van de Nederlandse derde weg (1989-2000)}

Hoe is deze toch wat merkwaardige situatie ontstaan? De geschiedenis van de Nederlandse Derde Weg vangt aan bij de grootschalige politieke omwentelingen die in de jaren rond de Val van de Muur plaatsvinden. Met de vorming van het CDA-PvdA kabinet Lubbers III op 7 november 1989, werd een veelomvattende transformatie van de sociaaldemocratie ingeluid. Zoals eerder gesteld bestond de kern van deze politieke gedaanteverandering - op inhoudelijk niveau - uit een macro-economische verschuiving van keynesiaanse vraagstimulering naar een gematigd neoliberale aanbodeconomie, een positiebepaling in het politieke midden en de nadruk op een activerende verzorgingsstaat en eigen verantwoordelijkheid. Vijf jaar later zou deze koers tot wasdom en bloei komen in de paarse kabinetten en nog eenzelfde periode later zou deze inhoudelijk uitgewerkt worden als het sociaalliberalisme van de Derde Weg.

De omslag kwam niet uit het niets. Het keynesianisme waar de PvdA onder Den Uyl haar socialistische politiek op baseerde, kwam in de jaren zeventig in een ernstige crisis terecht. In de jaren tachtig vond een reeks neoliberale hervormingen plaats, geleid door de kabinetten Lubbers (Touwen, 2010; Green-Pedersen, Van Kersbergen \& Hemerijck 2001; Scholten, 1987; Wolinetz 1989). Wilde de PvdA in beeld blijven als potentieel regeringspartner, dan diende zij afstand te nemen van de linkse polarisatiestrategie, van socialisme en Keynesianisme. In de internationale literatuur worden vaak electorale motieven (vote-seeking) genoemd als oorzaak van de opkomst van de Derde Weg (Kitschelt, 1994). In de Nederlandse casus zijn het niet zozeer electorale motieven - de PvdA haalde in de verkiezingen van 1977 en 1986 haar beste resultaten ooit. Het zijn bovenal politieke motieven (office-seeking) geweest - in het bijzonder de uitsluiting door andere regeringspartijen - die de PvdA dwong tot een herziening van haar politieke koers (GreenPedersen \& Van Kersbergen, 2002). Vervolgens heeft de partij dit vanwege electorale motieven naar buiten toe proberen te relativeren. Kort na de verkiezingen van 1986 volgde Wim Kok partijleider Den Uyl op, en werden 'de luiken opengezet' (Koole, 1993; Merkel e.a. 2008). Het daarop volgende vernieuwingsproject werd verwoord aan de hand van een aantal rapporten - Politiek à la Carte uit 1987, Schuivende Panelen en Bewogen Beweging in 1988 - waarin respectievelijk partijorganisatie, inhoudelijke koers en strategie werden behandeld. In Schuivende Panelen, geschreven onder leiding van partijprominent Jan Pronk, werd op voorzichtige wijze marktwerking omarmd. Van de hand van Paul Kalma verscheen in 1988 het essay Het socialisme op sterk water, een pleidooi voor een definitief afscheid van de traditionele socialistische ideologie, begrepen als een verlangen naar radicale maatschappijverandering. In plaats daarvan zou een 'minimaal socialisme' moeten komen dat zijn eigen beperkingen kent, zonder pretentie 'een algemene 
visie op mens en maatschappij te bezitten of te kunnen ontwikkelen'. (Kalma, 1988, 21)

In een lezing aan de universiteit van Nijmegen in 1989 nam Kok afstand van 'het streven naar het Grote Doel'. In een opvallende gelijkenis met de bekende uitspraak van Margaret Thatcher - There Is No Alternative (TINA) - stelde Kok dat er 'geen alternatief [is] voor de maatschappelijke constellatie die we nu hebben en dus heeft het geen enkele zin daar naar te streven.' (Marijnissen, 2010, 35) In de inmiddels beroemde Den Uyl-lezing uit 1995 werd het afscheid nog een keer dunnetjes over gedaan. Kok sprak van 'de bevrijdende werking van het afschudden van de ideologische veren'. En hij citeerde Paul Kalma instemmend: 'Een werkelijke vernieuwing van de $\operatorname{PvdA}$ begint daarom met een definitief afscheid van de socialistische ideologie; met een definitieve verbreking van de ideologische banden met andere nazaten van de traditionele socialistische beweging.' (Kok, 1995) Om er vervolgens aan toe te voegen dat dit verbreken van de banden in 1995 zo goed als voltooid was.

In tegenstelling tot de Verenigde Staten en Groot Brittannië echter, waar The Third Way met veel tamtam expliciet als nieuwe ideologie wereldkundig werd gemaakt door Bill Clinton, Tony Blair en de socioloog Anthony Giddens, waakte Wim Kok er voor om zich op die wijze te profileren. In zijn State of the Union in 1998 zou Bill Clinton triomfantelijk stellen: 'We zijn voorbij gegaan aan het steriele debat tussen degenen die zeggen dat de overheid de vijand is, en degenen die zeggen dat de overheid het antwoord is. Landgenoten, we hebben een derde weg gevonden.' (Geciteerd in Bos, 2010, 3) Een jaar later vond in Washington een bijeenkomst plaats over de Derde Weg, waar Wim Kok fungeerde als eregast. Clinton introduceerde hem als volgt: 'Wim Kok, uit Nederland, deed dit allemaal al voordat wij ermee bezig gingen. Hij wist het enkel niet - hij had niemand die er een goed label op kon plakken.' Kok gaf vervolgens schoorvoetend toe dat hij het 'in de praktijk bracht zonder het bijbehorende label te hebben, de Derde Weg'. (Bos, 2010, 4) Wat Clinton over het hoofd zag, is dat Wim Kok politieke redenen had om niet gelabeld te willen worden. Kok nam dan ook gelijk weer afstand van de term, want het ging eigenlijk om een brede boulevard met vele wegen. Binnenskamers gaf Wim Kok toe een groot voorstander te zijn van de Derde Weg (Giddens, 1998, 5). Publiekelijk liet Kok weten dat er geen behoefte meer was aan grote verhalen. Op het 21e congres van de Socialistische Internationale in Parijs adviseerde Wim Kok 'zijn internationale kameraden om niet te uitbundig met het Derde Weg-etiket te wapperen. Het gaat om vernieuwing, niet om terminologie. ${ }^{15} \mathrm{Dit}$ in scherp contrast met de Britse en Amerikaanse casus, waar juist een omvangrijke nieuwe terminologie geïntroduceerd werd - te beginnen met de naam van de partij: New Democrats en New Labour - om zogezegd een 'manicheïstisch contrast' te markeren met het verleden (Randall, 2009, 196).

Terugkijkend op deze periode in het tijdschrift Socialisme \& Democratie zou de PvdA-econoom Paul de Beer (zelf een voorstander van de Derde Weg) stellen dat 
onder Kok de nieuwe koers werd verhuld achter het compromis met coalitiepartij VVD. In het essay beschrijft De Beer een strijd binnen de partij tussen een 'klassieke' sociaal-democratische stroming, ook wel als vakbondsvleugel aangeduid, en een 'moderne' sociaalliberale stroming. De vakbondsvleugel, aldus De Beer, bepleitte een sterke positie van de staat, beteugeling van de markt, beperking van inkomensverschillen en een prominente rol van de vakbeweging. De sociaalliberalen daarentegen, gingen uit van de beperkte sturingsmogelijkheden van de overheid, wilden sociale doeleinden realiseren via de markt, en prefereerden gelijke kansen boven gelijke uitkomsten. Deze richtingenstrijd werd volgens Paul de Beer echter zoveel mogelijk bedekt. Toen de PvdA in 1994 een historische coalitie met de VVD aanging en vervolgens opging in paars, koos de partij voor een sociaalliberale koers die volgens De Beer echter niet als zodanig werd aangekondigd:

'De liberale inbreng in dit kabinet kon aan de VVD worden overgelaten, zodat de PvdA ogenschijnlijk aan haar meer traditionele standpunten kon vasthouden, zij het tot sociaalliberaal kabinetsbeleid verdund. Zo sloeg de PvdA, nota bene onder leiding van oud-vakbondsman Wim Kok, in de jaren negentig een geheel nieuwe weg in, zonder dat hierover een serieus intern debat was gevoerd.' (De Beer, 2004, 68)

De Beer eindigt het essay met een pleidooi voor het explicieter uitdragen van de Derde Weg als oplossing voor de politieke problemen van de PvdA. Eenzelfde geluid is te horen bij het dramatische verlies van de PvdA in de verkiezingen van 2002. Deze werd door partij-intellectuelen bovenal geweten aan de verlegenheid van de PvdA-top om de nieuwe politieke lijn expliciet te maken in de tijd van paars. Frans Becker en René Cuperus zouden in 2002 op verhelderende wijze schrijven:

'Paars werd, in termen van een sociaal-liberale middenkoers voor de PvdA, geïnternaliseerd door hooguit vier bewindslieden en drie kamerleden. De rest van partijkader en achterban zat met de rode billen samengeknepen zich ongemakkelijk tot paars en 'klassenvijand' VVD te verhouden. [...] Paars is nooit geïnternaliseerd door de PvdA-achterban; integendeel, bij velen bestond het gevoel dat de liberalen in paars aan het langste eind trokken. De partijleiding heeft de weerstand niet gevoeld, opgezocht en overwonnen. [...] De feitelijke koers Kok, de flirt met de centrumpositie in het Nederlandse politieke spectrum van de sociaaldemocratie door een gecombineerde oriëntatie op een sterke aanbodeconomie én een moderne, activerende verzorgingsstaat, is niet meer tot onderwerp van debat en programmatische vernieuwing gemaakt in $\operatorname{de} \operatorname{PvdA}$ na de heftige WAO-debatten uit het begin van de jaren negentig. Geen moedige Clause Four-confrontaties tussen Kok en zijn partij, laat staan een eigen ontwerp van een Hollandse derde weg-variant. Er was slechts die ene Den Uyl-lezing, het afschudden van de ideologische veren, maar die bleef zonder enig vervolg, als een openingszet in een nooit afgemaakte schaakpartij.' (Becker en Cuperus, 2002, 84) 


\section{De aarzelende 'coming out' van de Derde Weg (2000-2012)}

Aangezien Wim Kok geen oren had naar een nieuw verhaal dat de koersverandering expliciet zou maken kwam het zogeheten Derde-Wegdebat (De Beus, 2000) pas goed op gang aan het einde van zijn termijn. In de sociaaldemocratische literatuur is op dit punt herhaaldelijk de klacht terug te vinden, geuit door voorstanders van de Derde Weg, dat de eigen politieke koers niet openlijk naar buiten toe wordt gecommuniceerd. De 'PvdA moet zich met overtuiging op de Derde Weg richten', adviseert René Cuperus in een NRC-opiniestuk in 2000. De partij 'zal zich meer dan tot nog toe de feitelijke koers-Kok moeten toe-eigenen en zich deze meer eigen moeten maken'. ${ }^{16}$ PvdA-bestuurder Gritta Nottelman en de al genoemde politicoloog Kees van Kersbergen stellen in 2001: 'Het eerlijk uitkomen voor de derde weg is de manier om de partij weer een ideologisch verenkleed aan te meten.' (Nottelman \& Van Kersbergen, 2001, 40)

De roep binnen de PvdA om de nieuwe middenkoers expliciet te omarmen viel samen met de gezamenlijke internationale promotie van de Derde Weg door Giddens, Blair en Schröder. In de jaren 1999, 2000 en 2001 verschijnt er een reeks aan publicaties, waarin de partijtop van de PvdA zich voorzichtig verbindt aan de Derde Weg en daarbij een soort tussenkoers voorstaat tussen het Angelsaksische en continentale model (Cuperus \& Kandel 1998). De ideeën over de Derde Weg worden voornamelijk uit het buitenland geïmporteerd. Bovenal uit Groot-Brittannië, waar in 1994 New Labour aan de macht was gekomen en Tony Blair samen met de socioloog Anthony Giddens met de nodige zendingsdrang het nieuwe verhaal over de wereld verspreidde. Veel van de veranderingen die de nieuwe koers behelsde, kwamen samen onder de noemer van het 'radicale midden', een van die onmisbare Derde Weg termen. De oorsprong ligt bij Anthony Giddens, die in 1994 in Beyond Left and Right een nieuwe invulling gaf aan concepten als radicaliteit en progressiviteit. Volgens Giddens was radicaliteit in feite een synoniem voor progressiviteit en betekende het bovenal veranderingszin en het idee dat de geschiedenis in dienst gesteld kan worden van menselijke voornemens. Een vorm van maakbaarheid dus. Dat optimisme was nu bovenal bij het neoliberalisme en het (neo)conservatisme te vinden. Terwijl het socialisme juist conservatief was geworden, omdat het zich richtte op het behoud van de verzorgingsstaat. Giddens stelde een nieuwe radicale politiek voor, waarbij het woord 'radicaal' vernieuwing inhoudt ten opzichte van het bestaande linkse gedachtegoed.

Dat is niet enkel semantiek. Voor Den Uyl betekende progressiviteit 'nooit alleen wil tot verandering', het is verandering in de richting van gelijkheid gerealiseerd door herverdeling van kennis, inkomen en macht. (Den Uyl, 1978, 64) Dat streven uitte zich aan de hand van een polarisatiestrategie, oftewel en positionering op de linkervleugel, tegenover de VVD, die werd uitgesloten als potentiële regeringspartner. Met de keuze voor het radicale midden neemt de PvdA afstand van de polarisatiestrategie, de linkse positionering wordt ingewisseld voor een oriën- 
tatie op het midden. Progressiviteit krijgt een nieuwe betekenis aangemeten, en refereert niet zozeer aan gelijkheid als wel aan 'vernieuwing' ten opzichte van bestaande formules. In Leven na Paars?, nemen Jet Bussemaker en Rick van der Ploeg (2001) het begrip 'radicale midden' over. Het woord radicaal staat volgens hen voor de bereidheid om te breken met 'bestaand overheidsbeleid' en 'gevestigd socialistisch denken' (Bussemaker en Van der Ploeg, 2001, 20). Het radicale midden, zo stelde Ad Melkert in november 2001 bij de presentatie van het boek, moet begrepen worden als 'de bereidheid tot ingrijpende maatschappelijke vernieuwing in combinatie met het verwerven van een breed draagvlak voor verandering' (Bos, 2002, 64).

Het 'radicale midden' zou een richtsnoer blijven voor de politieke ontwikkeling van de PvdA onder Bos, die Melkert opvolgde en door de Britse spindoctor Peter Mandelson tot darling van de Derde Weg werd gebombardeerd. Het 'radicale midden' was de grote belofte van paars, aldus Bos, een belofte die door paars niet volledig was waargemaakt: 'Deze mogelijkheid tot radicaliteit in combinatie met een groot draagvlak, ontstaan door de overbrugging van traditionele links-rechtsscheidslijnen, blijft wat mij betreft de grote belofte van paars. Een belofte ook die helaas op een heleboel punten niet is ingelost.' (Bos, 2002, 62) Dat grote draagvlak, zo voegde hij daaraan toe, dat kon alleen in het politieke midden gevonden worden. Deze overbrugging werd in praktische zin gerealiseerd door het uitruilen van standpunten in plaats van het compromis: 'de politieke ruil' zag Bos als 'een typisch paars fenomeen'. (Bos, 2002, 61)

Door de Fortuyn-revolte van 2002 kreeg het woord paars - dat in Nederland als het veel bekendere synoniem fungeerde voor de Derde Weg - echter al snel een nare bijsmaak. Als gevolg daarvan verdween de term vrijwel geheel uit het publieke debat. Pas in 2010, rijkelijk laat, zou Wouter Bos in de toenmalige Den Uyl-lezing een poging doen de Nederlandse Derde Weg te theoretiseren, of naar eigen zeggen 'een plek te geven in de ontwikkeling van het sociaal democratische gedachtegoed' (Bos, 2010, 1) Maar ook hier vinden we een strategische ontkenning van het specifieke karakter van die vernieuwing: de Derde Weg was volgens Bos 'geen overwinning van de sociaal-liberalen op meer traditionele sociaal-democraten maar was mainstream sociaaldemocratie, niet meer en niet minder' (Bos, $2010,6)$ Er was geen sprake van 'grote opzichtige breuken ten opzichte van het verleden', enkel een zeer geleidelijke en noodzakelijke correctie van een overmatig geloof in het kunnen van de overheid (Bos, 2010, 6). En terwijl de Derde Weg volgens Bos bestond uit een 'relativering van de staat', 'een herwaardering van de markt' en meer 'verantwoordelijkheid' voor mensen zelf, stelde hij dat de coïncidentie van neoliberalisme en Derde Weg enkel het gevolg was van 'tragische timing'. De 'leidende deelname van de Partij van de Arbeid aan twee Paarse kabinetten' viel helaas samen met de opkomst van het neoliberalisme en de ontketening van het kapitalisme (Bos 2010, 6). Daarbij ontkende Wouter Bos nogal categorisch de bepalende invloed van het Britse Derde Weg denken op de PvdA (en op hemzelf): 'de Derde Weg kwam voor de Partij van de Arbeid niet van buiten, we deden geen anderen na, nee, het kwam van binnen en we waren er in veel opzich- 
ten eerder bij dan onze partijgenoten in het Verenigd Koninkrijk of de Verenigde Staten' (Bos, 2010, 6-7). Wat de verwarring naderhand compleet maakte, is dat de lezing van Bos ook nog eens verkeerd werd weergegeven door de Nederlandse journalistiek als zijnde een afscheid van de Derde Weg (Keulen \& Kroeze, 2010). Terwijl Wouter Bos toch echt aandrong op 'een begripvolle herwaardering':

'Wie hier vanavond naar toe kwam met het idee: eindelijk gaat die Bos in een oude schuilkerk eens boete doen als spijtoptant van het zondig ras der reformisten, ja zelfs het zondig ras der sociaal-liberale derde weggers, die komt bedrogen uit. Nou ja, half bedrogen dan toch in ieder geval. Want de vermaledijde derde weg is zeker een biecht waard, maar verdient ook een begripvolle herwaardering.' (Bos, 2010, 1)

\section{De omslag naar het gemeenschapsdenken onder Samsom en Asscher (2012- heden)}

Als we de Den Uyl lezing van Wouter Bos lezen als een herwaardering en daarmee voortzetting van de Derde Weg, dan doemt natuurlijk de vraag op in hoeverre de huidige politiek van de PvdA te begrijpen is in die termen. Opvallend is dat de regering Rutte II - die in strikt kleurtechnische zin eveneens een paarse regering is - misschien wel een getrouwere belichaming van Derde Weg-politiek is dan de paarse kabinetten onder Kok. Onder Kok was het gemeenschapselement en de herdefinitie van solidariteit in termen van rechten en plichten namelijk nog minder sterk aanwezig. In deze laatste sectie zal ik beargumenteren waarom Rutte II als voortzetting en vervolmaking van de Derde Weg kan worden gezien, om vervolgens een toespraak van Asscher te behandelen als toonbeeld van deze koers.

De thematiek van het radicale midden vinden we eveneens terug bij de regeringRutte II. Het regeerakkoord draagt niet voor niets de titel Bruggen slaan: de overbrugging van traditionele links-rechts scheidslijnen die Wouter Bos als kern van de Derde Weg ziet, is de officiële raison d'être van het kabinet. Er wordt 'radicaal' afgerekend met bestaand overheidsbeleid - de verzorgingsstaat maakt plaats voor de participatiesamenleving -en gevestigd sociaaldemocratisch denken- de anticyclische politiek. Daarnaast stonden de onderhandelingen tijdens de regeringsvorming in het teken van de ruil: de beruchte lijstjes van Rutte en Samsom. Wie daarbij nog de recente uitspraken van Samsom en Asscher erop naleest - die hun beleid legitimeren met een herhaaldelijk terugkerend beroep op 'draagvlak' - kan concluderen dat de belofte van paars waar Bos van sprak, met Rutte II lijkt te zijn ingelost.

Als we weer even teruggrijpen op de definitie Van Kersbergen, dan heeft de Derde Weg een beleidsmatig, een ideologisch, en een politiek-electoraal aspect. Dat politiek-electorale aspect is het zoeken van draagvlak voor derde-weg-beleid: 'een heroverweging van de electorale en politieke coalities', 'die het draagvlak voor het derde-weg beleid dienen te vormen' (Van Kersbergen, 2000, 280). Belangrijk is dat beleid en ideologie leidend zijn in de definitie van Van Kersbergen en dat elec- 
torale en politieke coalities daar een afgeleide van zijn. Bij Samsom en Asscher is dit ook duidelijk te zien. De regering Rutte II kenmerkt zich immers door een aantoonbaar gebrek aan draagvlak - het is volgens de peilingen een van de minst populaire regeringen in de Nederlandse geschiedenis. Zij verdedigen het regeringsbeleid echter met een beroep op het 'draagvlak', dat zou zijn gecreëerd. ${ }^{17}$ Dat brengt iets aan het licht, namelijk dat 'draagvlak' feitelijk als synoniem wordt gebruikt voor het varen van een centristische Derde Weg koers, ook al is daar bijzonder weinig draagvlak voor te vinden onder de bevolking, die liever een uitgesproken rechtse of linkse regering zou zien. De middenkoers is dus geen pragmatische maar een principiële keuze die zelfs wordt doorgezet als daar op electoraal gebied veel mee te verliezen is.

Ook als we kijken naar de beleidsmatige en politiek-ideologische aspecten van de Derde Weg, dan zien we veel parallellen met het beleid van de regering Rutte II. Het hoofdthema van het beleid van Rutte II, de opkomst van de participatiesamenleving, gaat uit van wederkerige solidariteit en de opkomst van de moraliserende overheid op het gebied van sociale zekerheid en zorg. De sociale investeringsstaat die macht decentraliseert is terug te vinden in de decentralisering van sociaal beleid naar de gemeenten. Daarnaast is er de sociaal-liberale modernisering van de sociale zekerheid onder Jette Kleinsma, expliciet gelegitimeerd in termen van wederkerige solidariteit en het aanzetten van mensen tot risiconemend gedrag. Ten derde is er een pro-cyclisch, monetaristisch beleid, uitgedragen door Dijsselbloem en verordonneerd door de ECB en Brussel. De beruchte banenplannen van Lodewijk Asscher zijn een sociaal-liberale breuk met het meer traditioneel sociaal-democratische 'dirigisme' van zijn voorganger Melkert. ${ }^{18}$ Zo bezien is het kabinet Rutte/Asscher de voorlopige culminatie van vijfentwintig jaar Derde Weg.

Een belangrijk verschil tussen de Nederlandse en de Britse Derde Weg is dat in Groot-Brittannië het gemeenschapsdenken van begin af aan een belangrijk onderdeel vormde van deze nieuwe politiek. De Nederlandse Derde Weg kende aanvankelijk een meer individualistische inslag (met als gevolg dat het CDA als eerste aan de haal ging met het Derde Weg-gemeenschapsdenken, uitlopend op het normen en waarden debat onder Balkenende). De Britse Derde Weg inspireerde zich op het communitarisme van Amitai Etzioni, John Macmurray en in mindere mate progressieve communitaristen als Alasdair MacIntyre, Michael Sandel, Charles Taylor en Michael Walzer. (Hale, e.a., 2004) Een van de eerste beschrijvingen van de Britse Derde Weg (Le Grand, 1998) vatte deze nieuwe politiek dan ook samen onder de noemer 'CORA':

17 Zie bijvoorbeeld het interview met Diederik Samsom in Buitenhof op 27 oktober 2013. http:// www.npo.nl/buitenhof/27-10-2013/VPWON_1188014, geraadpleegd op 13 augustus 2015.

18 'Waar blijven Asschers banen?' Vrij Nederland, 20 januari 2016. 'Meer bewijs waarom activerend arbeidsbeleid niet werkt', De Correspondent, 19 februari 2014. https://decorrespondent.nl/760/ Meer-bewijs-waarom-activerend-arbeidsbeleid-niet-werkt/81212960840-88ba1756, geraadpleegd op 14 juni 2016. 'Het failliet van de Nederlandse werklozenindustrie', De Correspondent, 19 februari 2014. https://decorrespondent.nl/754/Het-failliet-van-de-Nederlandse-werklozenindustrie/80571805886-cdd71352, geraadpleegd op 14 juni 2016. 
- community: gemeenschapsdenken

- opportunity: ondernemerschap

- responsibility: eigen verantwoordelijkheid

- accountability: rekenschap die burgers en overheid aan elkaar moeten afleggen

Sinds 2012 is de PvdA gaan bewegen van een meer individualistische positie naar een meer op gemeenschap georiënteerde visie. De Van Waarde resolutie uit 2013 beroept zich op samenredzaamheid en gemeenschapszin als antwoord op een terugtredende overheid: 'Er moet een omslag komen van ik naar ons.' ${ }^{19}$ Maar de meest expliciete expressie van deze nieuwe koers vinden we in de destijds gehypte en inmiddels al bijna weer vergeten toespraak van Lodewijk Asscher, op 28 oktober 2012. ${ }^{20}$ Het was de zogenaamde Preek van de Leek, gehouden op een vrij belangrijk moment, vlak voor de vaststelling van het regeerakkoord van het kabinet Rutte II. Niet zonder reden was de zaal afgeladen met journalisten: de verwachting was dat hier een strategische lijn zou worden uitgezet. Asscher stelde niet teleur: door Vrij Nederland werd de preek prompt uitgeroepen tot de ideologische basis van het nieuwe kabinet. ${ }^{21}$

In het begin van zijn preek stelde Lodewijk Asscher: 'Ik geloof niet in TINA'. TINA is natuurlijk de afkorting van There Is No Alternative, een gevleugelde uitspraak van Margaret Thatcher, waarmee zij het neoliberalisme en het marktmechanisme als onvermijdelijk presenteerde. Asscher neemt dus de nodige afstand van het neoliberalisme, waar Bos en Samsom hem al in voorgegaan waren, alleen zonder daar iets duidelijks tegenover te stellen. De vernieuwing van Asscher is dat vrijwilligerswerk vanuit de gemeenschap als alternatief wordt aangedragen voor het marktmechanisme. Norman Fairclough, vooraanstaand onderzoeker op het gebied van discoursanalyse, identificeerde in zijn boek over de taal van New Labour (2000) het gemeenschapsdenken als bepalende element dat Tony Blair ertoe in staat stelde zich te distantiëren van Thatcher. Gemeenschapsdenkers als Macmurray combineren elementen van 'christelijk socialisme' met een 'conservatieve kritiek op het individualistische wereldbeeld van het liberalisme'. Deze combinatie 'verschafte Blair zijn onderscheidende positie, en een basis vanwaar hij het neoliberalisme van Thatcher kon bekritiseren'. (Fairclough, 2000, 38)

De preek van Asscher laat zich lezen als een pagina uit het script van Blair. De kern van Asschers betoog is te herleiden tot twee elementen die logischerwijs uit elkaar voortvloeien. Het eerste is een herformulering van het solidariteitsbegrip. Het tweede is de aankondiging een terugtredende overheid, waarvan de sociale kosten door de goede werken van de bevolking opgevangen dienen te worden. Solidariteit is voor Asscher niet langer iets dat verworven moet worden door politieke mobilisatie en dat gewaarborgd moet worden door instituties. Het is

19 Zie; http://www.pvda.nl/berichten/2013/02/PvdA+presenteert+resolutie+Over+wat+van +Waarde+is, geraadpleegd op 14 juni 2016.

20 Zie: http://www.preekvandeleek.nl/index.php/leken/leek/lodewijk_asscher/, geraadpleegd op 13 augustus 2015.

21 'Preek van de vicepremier', Vrij Nederland, 29 oktober 2012. 
bovenal een persoonlijke opgave. Het gaat erom ons te kunnen verplaatsen in de mensen die het minder hebben. Hiermee geeft Asscher een zeer charitatieve invulling aan het idee van solidariteit, waarbij het feitelijk gelijk wordt gesteld met vrijwilligerswerk. 'Verplaats je in anderen, bekommer je om anderen', zo preekt Asscher.

'Wees niet onverschillig en accepteer het onacceptabele niet. Er is altijd een alternatief! Begin nabij, het hoeft niet de armoede in de derde wereld te zijn, het hoeft niet meteen de vrede in het Midden-Oosten te zijn. Ook jouw Lazarus ligt waarschijnlijk gewoon voor je deur, woont naast je, heeft kinderen op de school van jouw kinderen, winkelt in dezelfde supermarkt.' (Asscher 2012, 4)

Volgens Kees Schuyt (1992) maakt het solidariteitsbegrip het fundament uit van de verzorgingsstaat. Bij Lodewijk Asscher is solidariteit juist het antwoord op haar verdere desintegratie. De burger moet volgens Asscher niet meer naar de overheid moet kijken, maar zelf dingen onder handen nemen:

'Wees niet onverschillig. Jij kunt een verschil maken. Doe dat dan ook. Verwacht niet dat een Ander het oplost. Een politicus, een held of een godheid. Je kan niet van de politiek verwachten dat zij alles oplossen. Je verwachtingen zijn dan niet reëel én je houdt ook op je af te vragen welke rol je zelf kunt spelen.' (Asscher 2012, 5)

Deze politiek zou een jaar later pas officieel door het kabinet verkondigd worden met de introductie van het begrip 'participatiesamenleving' in de troonrede van september 2013, geschreven door Rutte en Asscher. De beduchtheid van Kok, 'het gaat om vernieuwing, niet om terminologie', lijkt men even te zijn vergeten. Weliswaar is naderhand de term participatiesamenleving aan de VVD toegeschreven en heeft de $\operatorname{PvdA}$ na ontstane publieke controverse op inmiddels traditionele wijze de nodige afstand genomen van het idee. Maar het was Asscher, niet de VVD, die zich het eerste profileerde met dit thema.

Voorheen was de analyse dat de PvdA haar eigen Derde Weg moest vinden en zich niet al te veel moest vereenzelvigen met het Britse derde-weg- denken omdat dit gedachtegoed daar 'te conservatief voor ingekleurd' was (Wouter Bos, 2002, 63). Onder Asscher zijn de conservatieve elementen van het Britse derde-weg-denken geïncorporeerd in de koers van de PvdA. Nu is het zo dat de Derde Weg, samen met Tony Blair, in Engeland al een tijdje politiek dood is verklaard. New Labour heet gewoon weer Labour. Net als in Nederland na paars, leven de ideeën echter voort en is men verder gegaan onder de noemer Blue Labour, een gedachtegoed dat zich wat kritischer opstelt ten opzichte van de markt en meer inzet op gemeenschap, maar los van deze accentverschillen, voortborduurt op de Derde Weg van voorheen. De belangrijkste figuur van Blue Labour is Maurice Glasman, een Labour Lord en een controversieel denker die een eigen variant heeft ontwikkeld op de zeer vergelijkbare Big Society formule van de Britse Conservatieven. 
Glasman roept op tot een conservatieve Labour politiek. Niet voor niets staat Asscher bekend als een bewonderaar van Glasman, wiens ideeën hij omarmde tijdens een gezamenlijk debat in de Balie, op 1 februari 2012. ${ }^{22}$

\section{Conclusie}

Het sociaalliberalisme van de Derde Weg is nog immer een dominante stroming binnen de PvdA. De neiging van de partij om zich niet helemaal publiekelijk te bekennen tot de sociaalliberale koers en deze naar buiten toe te vermengen met sociaaldemocratische getuigenispolitiek, heeft tot een wat diffuus profiel geleid. Een gevolg van deze onduidelijkheid is dat er binnen de politieke wetenschap relatief weinig aandacht is besteed aan het gedachtegoed van de Nederlandse Derde Weg.

De Derde Weg kan onderverdeeld worden in een beleidsprogramma, een ideologisch discours en een politiek-electorale houding. Bekijken we al deze aspecten, dan vertoont het beleid van het huidige kabinet Rutte II veel overeenkomsten met het Derde Weg-denken. Het Nederlandse sociaal-liberalisme onderscheidde zich oorspronkelijk van haar Britse tegenhanger door de afwezigheid van een conservatief gemeenschapsdenken en door een meer individualistische inslag. Onder Samsom en Asscher heeft de PvdA zich verder in de richting van het Britse Derde Weg-denken bewogen.

De Derde Weg is in Nederland veelal tot pragmatisme gereduceerd, waardoor het ideologische karakter van dit gedachtegoed wat op de achtergrond is geraakt. Zo schrijven Green-Pedersen, Van Kersbergen en Hemerijck (2001) dat 'het beleidspragmatisme van de Derde Weg uitgaat van zowel een positieve visie aangaande het vermogen van de markt om bepaalde uitkomsten te genereren, en een sterke nadruk op de actieve sociale investeringsstaat.' De nadruk op pragmatisme is verwarrend, omdat zij zelf stellen dat het Blair-Schröder paper illustreert dat sociaaldemocraten nimmer beleid van ideologie hebben gescheiden (Green-Pedersen, e.a. 2001, 323).

Het is inmiddels duidelijk geworden dat bijvoorbeeld de privatiseringsgolf onder paars (Stellinga 2014) en het activerende arbeidsmarktbeleid (Den Butter \& Mihaylov 2008) vanwege de gebrekkige resultaten, beter vanuit ideologische dan pragmatische motieven begrepen kunnen worden. Dat geldt evenzeer voor het macro-economische beleid van de Derde Weg. De neoklassieke macro-economische consensus waaruit de Derde Weg is ontstaan, is inmiddels onderwerp van controverse. Het Keynesiaanse argument voor anticyclisch beleid beleeft een wederopleving. In deze context van botsende denkkaders komt het ideologische karakter van de Derde Weg sterker naar voren. 
Een kernidee van de Derde Weg was dat de toekomst van de Nederlandse politiek bepaald zou worden door de partijen die het politieke midden bevolken. Wouter Bos zou in 2002 schrijven over 'de slag om het midden die een constante zal zijn in de politiek van de komende decennia', het gevolg van langlopende 'demografische, sociologische en electorale ontwikkelingen' (Bos, 2002, 62). Dit is bij nader inzien een strategische vergissing gebleken. Het decennium daarna zou immers in het teken komen te staan van de politieke flanken. Donkere wolken pakken zich nu samen. De crisis van het politieke midden - af te lezen aan de volatiliteit van het kiesgedrag en de wederopleving van de flanken - is eveneens de crisis van de Derde Weg.

\section{Literatuur:}

Asscher, L. (2012). De preek van de leek. Geraadpleegd op 13 augustus 2015 via: http:// www.preekvandeleek.nl/index.php/leken/leek/lodewijk_asscher/, (28 oktober).

Becker, F. \& Cuperus, R. (2002) Alarmfase 1! Zonder grondig zelfonderzoek gaat het niet. $S \& D, 2002(5 / 6), 82-89$.

Beer, P. de (2004) 'Het debat over sociaal-liberalisme op herhaling', $S \& D$, 2004 (5-6), 68-73.

Beus, J. de (2000). De Europese sociaaldemocratie: Politiek zonder vijand. S\&D, 2000 (1): 10-14

Beus, J. de \& Notermans, T. (2000). Een taxatie van de derde weg. Beleid en Maatschappij 27(2): 78-92.

Blair, T. \& Schröder G. (1999) Europe: The Third Way / Die Neue Mitte. Herdrukt en van commentaar voorzien door Joanne Barkan in Dissent, 47(2), lente 2000, 51-65.

Blommaert, J. (2007) De crisis van de democratie: Commentaren op actuele politiek. Antwerpen: EPO.

Bos, W. (2002). Zoeken na(ar) Paars. S\&D 2002 (1), 60-64.

Bos, W. (2010) De Derde Weg voorbij: 21e Den Uyl lezing. http://www.pvda.nl/berichten/ 2010/01/Den+Uyl+lezing+Wouter+Bos, geraadpleegd op 14 juni 2016.

Bussemaker, J. en Ploeg, R. Van der (2001) 'Rood in Paars: visie op een links-radicale politiek', in: Bussemaker en Van der Ploeg, Leven na Paars?, Amsterdam: Prometheus, 11-40.

CDA (2012) Kiezen en verbinden. Politieke visie vanuit het radicale midden. Rapport CDA Strategisch Beraad, januari 2012.

Cuperus, R. \& Kandel, J. (red.) (1998). European social democracy; transformation in progress. Amsterdam: Friedrich Ebert Stiftung.

Daalder, H. (1995). Van oude en nieuwe regenten. Amsterdam: Bert Bakker.

Den Butter, F. \& Mihaylow, E. (2008) Activerend arbeidsmarktbeleid is vaak niet effectief. ESB april 2008, 61-63.

Den Uyl, J. (1978), Inzicht en Uitzicht. Opstellen over economie en politiek, Amsterdam: Bert Bakker.

Fairclough, N. (2000, 38), New Labour, New Language. London: Routledge.

Giddens, A. (1994) Beyond Left and Right: The future of radical politics. Stanford: Stanford University Press.

Giddens, A. (1998). The Third Way: The renewal of social democracy. Cambridge: Polity Press.

Giddens, A. (2000) The Third Way and its critics. Cambridge: Polity Press. 
Green-Pedersen, C., Kersbergen K. van \& Hemerijck, A. (2001) Neo-liberalism, the 'third way' or what? Recent social democratic welfare policies in Danmark and the Netherlands, Journal of European Public Policy, 8 (2): 307-325.

Green-Pedersen, C., \& Kersbergen, K. van (2002) The Politics of the 'Third Way'. The Transformation of Social Democracy in Denmark and the Netherlands, Party Politics, 8 (5): 507-24.

Hale, S., Leggett, W. \& Martell, L. (red.) (2004). The Third Way and Beyond: Criticisms, Futures and Alternatives. Manchester: Manchester University Press.

Hoop, R. (2004). Social policy in Belgium and the Netherlands: Third Way or not? In: G. Bonoli \& M Powell (red.) Social democratic party policies in contemporary Europe, Londen: Routledge.

Kersbergen, K. van (2000) 'De Onontkoombaarheid van de 'Derde Weg'. Socialisme en Democratie, 6: 275-83.

Kersbergen, K. van \& Nottelman, G. (2001). 'De derde weg en de Nederlandse politiek', in: J. Bussemaker en R. van der Ploeg (red.), Leven na Paars?, Amsterdam: Prometheus, 40-51.

Kalma, P. (1988) Het socialisme op sterk water. Veertien stellingen. Houten: Springer Media.

Keulen, S. \& Kroeze, R. (2010). Breken met het verleden. S\&D, 2010 (3): 54-62.

Kitschelt, H. (1994) The Transformation of European Social Democracy. Cambridge: Cambridge University Press.

Kok, W. (2009 [1995]) We laten niemand los, in: In het spoor van den Uyl. Den Uyl lezingen 1988-2008, Amsterdam : Stichting Dr.J.M. den Uyl-lezing, 187-216.

Koole, R. (1993) De ondergang van de sociaaldemocratie: De PvdA in vergelijkend en historisch perspectief. $S \& D, 1993$ (7): 73-98.

Le Grand, J. (1998), 'The Third Way begins with Cora', New Statesman, 6 maart 1998, 26-27.

Lewis, J. \& Surender, R. (red.) (2004). Welfare State Change : Towards a Third Way? Oxford: Oxford University Press

Lukes, S. (2000). Een doodlopende weg? Het laatste woord over de derde weg. Beleid en Maatschappij 27(2): 99-100.

Marijnissen, J. (2010) Tegenstemmen: een antwoord op het neoliberalisme. Amsterdam: L.J. Veen.

Merkel, W., Petring, A. Henkes, C \& Egle, C. (2008) Social Democracy in power: The capacity to reform. Londen: Routledge.

Praag, P. van (1991) Strategie en illusie. elfjaar intern debat in de PdvA (1966-1977). Amsterdam: Het Spinhuis.

PvdA (2007). De scherven opgeveegd: een bericht aan onze partijgenoten. Rapport van de commissie-Vreeman aangeboden aan het bestuur van de PvdA op 30 mei 2007. Den Haag: PvdA.

Randall, N. (2009) Time and British politics: memory, the present and teleology in the politics of New Labour. British Politics (4)2, 188-216.

Scholten, I. (1987), 'Corporatism and the Neo-Liberal backlash in the Nether- lands.' In: Ilja Scholten, ed., Political Stability and Neo-Corporatism. London: Sage, 120-152.

Schuyt, C.J.M. (1992), Op zoek naar het hart van de verzorgingsstaat, Leiden: Stenfert Kroese.

Spithoven, A. (2002). The Third Way: The Dutch experience. Economy and Society, 31 (3): 333-368.

Stellinga, B. (2014) Dertig jaar privatisering, verzelfstandiging en marktwerking. Amsterdam: AUP.

Touwen, J. (2014). Coordination in transition: The Netherlands and the world economy, 19502010, Leiden: Brill 
Tromp, B. (2010) De Crisis der partijen en enkele voorstellen deze te overwinnen. In B. Tromp, Geschriften van een intellectuele glazenwasser. Amsterdam: Bert Bakker, 251-273.

Wolinetz, S. (1989). Socio-economic bargaining in the Netherlands: Redefining the postwar policy coalition. West European Politics, 12(1), 79-98.

Wolinetz, S. (1993) 'Reconstructing Dutch Social Democracy', West European Politics 16(1): 97-111.

Wolinetz, S. (1995) 'The Dutch Parliamentary Election of 1994', West European Politics 18(1): 188-93.

Wolinetz, S. (1996) 'Internal Politics and Rates of Change in the Partij van de Arbeid 19571994', In: G. Voerman (ed.), DNPP Jaarboek 1995, Groningen: DNPP, 113-126;

Wöltgens, T. (1998). De ideologie van paars. S\&D, 1998 (9), 371-376. 